\title{
Nature of Commitment in the General Conditions of FIDIC, Iran Construction Contracts, and Principles of European Law on Service Contracts
}

\author{
Mohammad Ghahraman ${ }^{1} \&$ Masoud Reza Ranjbar Sahrayi ${ }^{1}$ \\ ${ }^{1}$ Department of law, Shiraz Branch, Islamic Azad University, Shiraz, Iran \\ Correspondence: Mohammad Ghahraman, Department of law, Shiraz Branch, Islamic Azad University, Shiraz, \\ Iran. E-mail: mm_gharaman@yahoo.com
}

Received: September 4, 2016

Accepted: October 2, 2016 Online Published: December 29, 2016

doi:10.5539/jpl.v10n1p166

\author{
URL: http://dx.doi.org/10.5539/jpl.v10n1p166
}

\begin{abstract}
Commitment is a consequence of a contract. Identifying the nature of commitment is very important to achieve it. The question here is that what is the nature of commitment in construction contracts? Is the constructor bound to achieve a result and implement the contract subject, or is his/her effort to implement the contract subject enough? Since performance of the contract subject in construction contracts, which include creating, repairing and reconstructing a building, requires time passing and meeting various secondary commitments by both parties, the issue was studied according to the general conditions of FIDIC (International Federation of Consulting Engineers) contracts, Iranian Organization of Management and Planning and Principles of European Law on Service Contracts.
\end{abstract}

Keywords: general conditions of FIDIC contracts, principles of European law on service contracts, employer, contractor

\section{Introduction}

In the recent years, rapid progress of technology and industrial innovations have caused some verifications in construction contracts and their underlying conditions to be compatible with the progresses. The manifestation of various contracts having numerous commitments is a consequence of huge changes in construction which were not present in the last era in such form, or maybe were not needed or regarded by people and the society. Irregular growth of population, protecting the rights of both parties in a contract, observing the balance and regularity in the social system necessitate regulation of contracts, commitments and their underlying conditions more accurately by observing the balance.

Today, traditional or oral contracts are not effective in the relationships among employers and constructors. The process of constructing complicated and technical buildings with various productions and deadlines for meeting commitments of both parties require time and transparency in meeting the commitments. Therefore, some organizations are established in the internal and international levels to create a balance, homogenize the commitments and prepare diverse contracts with various conditions. In Iran, the Ministry of Roads and Urban Development and the Organization of Management and Planning, and at the international level, Consulting Engineers' Institution called FIDIC have prepared various books and conditions and presented numerous draft contracts and general conditions with different subjects in order to control buildings and supervising them. In the present study, a question was investigated that what is the nature of the commitment of both parties in construction contracts based on the conditions written in contract templates? How much the constructor should try to fulfill the mentioned conditions and commitments?

\section{Literal and Technical Meanings of Commitment}

Some lawyers believe that in the current law, commitment has two meanings: A. The general meaning which includes all religious rights, B. The specific meaning which refers to the liabilities arising from a contract, and it is against the non-contractual obligation (Katozian, 2000). Arab lawyers believe that commitment is an obligation (Alsanhouri, 1970), but in the Civil Code of Iran, "Commitment" refers to liabilities arising from a contract (Katouzian, 2000). Commitment is considered as something that should be observed and responsibility means obligation (Jafari Langroudi, 1984). In Imamiya jurisprudence, the contract means commitment 
(Alhosseini Almaraqi, 2004). Commitment is a legal relationship which obliges a person to transfer or deliver a property to someone or do a task, whether the cause of this relationship is a contract, a cadence or a natural obligation (Katozian, 2000). Therefore, in this legal relationship, the religious right is considered as the positive face, and the commitment or liability is considered as the negative face. In the general conditions of contracts (Yellow Book, FIDIC, 2014), performing the main commitment of each party is a function of the process called secondary commitments or conditions terms of contract which delineates the way of performing the main commitment during the contract duration.

\section{Domain of the Principles of European Law on Service Contracts (PELSC)}

Service contracts in the European Union (EU) are of great importance. The European Union has been established based on the contracts signed by its members. These contracts are in fact some rules implemented in the countries listed in this union. The European Commission (EC) proposed a guideline in 1998 (com - $90-482-$ ojc- 12/8-18 January 1998) which finally led to approve the principles of European law on service contracts including 7 chapters (Barendrech et al., 2007). The second chapter includes the rules and general commitments of both parties in construction contracts. The main commitments of both parties are commitment to cooperation and observation, compliance, inspection, supervision, acceptance, delivering the building, paying the price, risks, and implementation of the exact commitment. According to the article 1-101, the above mentioned principles are dominant in all construction contracts in which one party is bounded to construct a building or an immobile structure or make a rational change in other immobile structures following a design prepared by the employer (Ibid). The above mentioned principles are under the power of the European law on service contracts. In most countries such as England, Sweden, and Finland, although some codified rules have been established in consumption contract, there is no codified rules about construction activities (Consumer Protection ACT, 2008). However, some countries such as Netherland, France and Spain have established some rules for construction. In the civil code of most European countries, there are some rules about construction activities, e.g. article 7-750 in Dutch Civil Code, article 1710 in the Belgian Civil Code, article 1787 in the French Civil Code, article 1544 in the Spanish Civil Code, articles 1655 to 1677 in the Italian Civil Code, article 1151 in the Civil Code of Germany, article 1544 in the Greek Civil Code, article 1151 in the Austrian Civil Code. However, the above mentioned rules are influenced by judicial trend, general rules and conditions of FIDIC (no $-37-100$ ، 1955, Wallace).

There is not a specific legal regime on construction in England, although there are some common forms and patterns called ice, and jct. In Germany, there is a rule on construction activities in the domain of the civil code (article 631) and a series of conditions called VOB. In other European countries such as Spain, there are similar rules and conditions called LOE. In Austria it is called ONORM, 2060, and in Netherland it is called AVA, 1992-UAV, 2010.

\section{Domain of General Conditions of a FIDIC Contract and its Purpose}

The International Federation of Consulting Engineers, FIDIC, was established in 1913 and started its activities with a limited number of countries, but many countries have joined them up to now. This institution which is located in the Geneva World Trade Center, Switzerland, represents the construction industry in different dimensions, tries to develop and complete technical and legal rules associated with employers and contractors and prepare contract templates in order to create a balance in their rights and commitments. This institution has been published the contracts and general conditions of various contracts since 1945 entitled Red Book, Yellow Book, Silver Book, Orange Book, etc. in accordance to the needs. The Red Book and the Silver Book are the most important ones. FIDIC rules are international. However, this does not prevent them from being used in interior tenders and contracts. The aims of preparing the mentioned conditions include: 1 . Creating a balance in the rights and commitments of both parties, 2. Proper allocation of the risks of construction processes among both parties, 3. Facilitating the relationships between employers and contractors.

\section{The Concept of the Nature of Commitment}

Commitment is a consequence of a contract. The obligatory power of a contract is based on the fact that its arising commitments are also obligatory. It is difficult to prove the performance of commitment and to achieve the goal of a contract. Lawyers are trying to identify some solutions to prove the blame. According to the article 1328 in the French Civil Code, any act done by a person that cause a damage to another person is bound over if the damage is originated from his/her fault and finally he/she is responsible for compensating the damage, and everyone is bailsman of the damages caused by his/her own carelessness and negligence. The article 282 in the Civil Code of Iran, also confirms this issue. Therefore, committing a fault is the criterion of the guilty person responsibility. French lawyers (Demog and Vemaso) suggested a classification called "Commitment to result and 
commitment to means" to define the nature of commitment (Mortazavi, 2013). Therefore, if the committed party undertakes responsibility of the result, it is a commitment to result. If he/she do his/her best to achieve the result and does not bound to achieve the result, it is a commitment to means. Usually in such commitments, it is necessary to prove the fault of the committed party, and it should be proved that the committed party does not act like an ordinary person (Ibid, 22). Some authors have addressed the role of a commitment type in proving the fault, so that not achieving the commitment to result is considered as a fault (Katozian, 2000, 56), and some other authors believe that in commitment to result, prove of innocence is not effective because the guilt is assumed (Ghasemzadeh, 2009). In the French law, some lawyers are of the same opinion, and they even believe that in commitment to means, the guilt rate is not effective (Alsanhouri, 1970). In the Egyptian law, the guilt rate is also not effective. In commitment to result, just proving innocence is not sufficient for being free of responsibility, but it is necessary to prove interference of an external event. Therefore, identifying the nature of commitment is very important, and it can be the best way to interpret the mutual consent (Katozian, 2000). There are some criticisms on the above mentioned classification. Some ones believe that separating commitment to means and commitment to result is not based on a specific legal analysis and it is a useless separation. These two subjects do not result in differences in legal sequences. The nature of the commitment subject determines the commitment limits, and the committed party is bound to perform the subject that is responsible for it (Shahidi, 2004). Therefore, the commitment subject cannot be a criterion of recognizing justification of the reason. Despite the criticisms, for confirmation of the above mentioned classifications, it can be said that the main criterion is limits of the commitment that the committed party is bound to, and he/she should undertake the load of its achievement.

\section{Commitment to Result and Means and Distinguishing Them}

If the committed party guarantees achieving the commitment subject, it is called commitment to result. "Commitment to result is observed in the article 221 in the Civil Code of Iran because the committed party is responsible to perform the commitment that he/she is bound to, and in the case of a breach, he/she is responsible for compensating damages" (Mortazavi, 2013). If doing a given task is the subject, not achieving the result causes a responsibility, and there is no need to adduct an evidence for proving the guilt, and if not doing a task is the subject of a commitment, with regard to the presence of principle, the other party should prove the guilt of the committed party. The criterion of commitment to result follows a fixed limit, i.e. achieving the result (Katozian, 2005). When commitment to result does not depend on a likelihood, the committed party should present a certain result (Katozian 1985; Jafari Langroudi, 2003). This issue is considered in the jurisprudence books (Najafi, 1974) and the verdicts of the courts (Katozian 1999). However, when commitment needs providing preliminaries of a certain task, or trying and observing execution of a commitment, it is called commitment to means. "Sometimes the obligor assumes the responsibility of providing the means for achieving a desirable result, tries his/her best to reach this goal, and is careful" (Katozian, 1999). In this kind of commitment, the obligor is not bound to a certain result, and the other party should prove his/her guilt in performing the commitment. "The criterion for commitment, in commitment to means is different in different kinds of commitments and depends on the contract type. The criterion here is measuring the behavior of a conventional compassionate owner in performing the commitment, and the custom also may help" (Mortazavi, 2013). Now the question is that what is the criteria for distinguishing these two types of commitment? And in the case of doubt, which one is the principle? Lawyers have presented some criteria and the most important one include intention of both parties, capability of performing the commitment subject, and probability of the result, e.g. the result of judgment and medical practice. There are two important points in commitment to means. The first point is making use of necessary arrangement, and the second point is achieving the result. The first point should certainly be performed, but the second one is not under the power of the obligor (Ibid). In case of doubt, some lawyers consider a commitment to result in most contract commitments, unless the opposite is proved, and consider the commitment to means in the compulsory guarantee (Katozian, 2000). In this case, it can be said that because of the lack of a certain commitment in the compulsory guarantee, this classification is not fixed. However, since obtaining a common intention is not always simple, the best way is observing type of the task undertaken by the obligor (Katozian, 1987).

\section{Commitments of the Parties in Construction Contracts}

In construction contracts, the contract subject and the main commitment are usually constructing, repairing and reconstructing a building. The contractor is committed to the employee to construct a building, according to the contents and conditions written in the contract. Here, the question is that what kind of commitment is this commitment, and what is the extent of this commitment? Is the contractor bound to achieve the result, or do his/her best to achieve it? Distinguishing the commitment to result and commitment to means depends on the 
possibility grade that presents with regard to achieving the common goal. In the cases where the required result is obtained as a habit, commitment provides the result (Katozian, 1989). In constructing a building, according to the common procedures and human knowledge, achieving the result is required. Basically, the price written in the contract can be paid just in the case of achieving the result (Katozian, 1987). However, the question here is whether this issue is dominant in all constructions and with every kind of materials or not? In the other words, if the employer wants to construct a building with special materials and in special conditions, in which the possibility of achieving the result is weak based on the common procedure, is this principle dominant? Here, it is necessary to combine two criteria, including common intention and the possibility of achieving the result. In other words, the main criterion is the common intention of both parties. In the case of lack of an intention, the possibility of achieving the result, according to the custom, habit and ordinary procedure of affairs can be considered as the criterion. In the custom, habit and social system, according to ordinary contracts and conditions underlying them, the constructor should perform the required result and the main commitment written in the contract, unless not achieving the result does not attribute to him/her (Katozian, 1997).

\section{Nature of Commitment in FIDIC, Iran Construction Contracts and Principles of European Law on Service Contracts}

Since the present study aimed to identify the nature of commitment in general conditions of FIDIC and Iran Construction Contracts and Principles of European Law on Service Contracts, some of the commitments of the parties in the mentioned conditions and principles were addressed. According to the article 221 in the Civil Codes of Iran and articles no. 1, 7 and 8 in the Law of Pre-sales of Apartments approved in 2010 (Khodabakhsi, 2013), and the National Rules of Construction especially the second (administrative systems) and fourth subjects (general necessities of construction) and the twelfth subject (safety and protection) and general conditions of agreement by the Management Organization (articles no. 37, 41 and 42), the legislator and the contents of the mentioned conditions consider the commitment to the result as a principle.

The dominant condition of integrated agreements and the conditions of FIDIC show that the constructor should construct the given building and deliver it according to the technical principles, so that not achieving the subject of the contract would lead to presenting a claim to the court by the employee against the contractor. Numerous articles in different books of FIDIC confirm this issue. In the Red Book, in the chapter about delivering the building (suffix 10-1), it is prescribed that the works are delivered to the employer just when they are completed according to the contract, and the certificate of work completion is signed by the supervisor engineer. This term indicates the commitment to result (Red book -10-4-10-7-Axel, 2010, 162). According to the article 2-106 in the Principles of European Law on Service Contracts (PELSC, 2-106), the contractor is bound to deliver the building. If the constructor wants to transfer control of the building or any part of it, which is completed and can be used independently, the employer should accept this control in a common and rational time, which is done after the warning, and if it is not in accordance with the contract, the employer can refuse accepting it. Although accepting control of the building by the employer would not exempt the constructor completely or partially from his/her responsibility. Even where there is a commitment to inspection and supervision by the employer, this rule is dominant. Therefore, some commitments of both parties in the mentioned suffixes, principles and conditions are addressed in the following sections.

\section{Nature of the Employer Commitment and Some of Its Evidences}

The employer, as one of the parties in the contract, has some commitments. The main employer commitments in the general conditions of FIDIC, Iran Construction Contracts, Principles of European Law on Service Contracts and general conditions of agreements by the Management Organization are as follows: Delivering the land and site for the project and the related information (Red book 1-2, 2-102 EPC, PLESC, and article 28 in the general conditions of the Management Organization), paying the temporary and definite bills (Red book, 14.1, 14.6, PELSC, 2.107-EPC, and articles no. 37 and 39 in the general conditions of the Management Organization), taking the licenses and necessary orderings ( EPC-Red Book 3.1), providing materials and equipment based on the contract (Red Book EPC-7.1), paying the costume duties, delivering the works and independent parts (PEISE-1.106-Red Book-10.2, and articles no. 39 and 41 in general conditions of the Management Organization), commitment to compliance (-PELSC,2.102-Red Book-4.6), commitment to inspection, supervision and acceptance (EPC-Red Book -3.3-PEISE-2.105). Some of them are discussed briefly in the following sections.

\subsection{Delivering Workshop and Right of Access to the Site}

According to suffix 2-1 (Red Book, EPC, 2.1) in the general conditions of FIDIC contracts, especially the Red Book and the Silver book, which are two different and main patterns at the global level, the article 2-102 in the Principles of European Law on Service Contracts (PELSC-2.102), and the article 28 in the general conditions of 
agreement by the Management and Planning Organization, the employer is bound to deliver the workshop to the contractor for executing commitments before a deadline determined in the tender documents and the contract. If a delay occurs in this regard, and the contractor undergoes a charge, then the contractor proclaims it to the consulting engineer, he/she inspects it and in the case of deservingness of the contractor the contract duration would be elongated, expenditures would be determined (Red Book-EPC-2.1-3.5). However, if the guilt is resulted from the delay or mistake taken by the contractor, then the contractor does not have the right to elongate the contract duration and undertaken costs, because committing a guilt is the basis of responsibility in achieving conditions and secondary commitments, and lack of observing the contract conditions and escaping the permission are the basis of achieving a guilt (Katozian, 2005). In all judicial areas in Europe, the duties of employer to cooperate with the contractor are interpreted extensively. In England, this commitment is resulted from the implicit conditions (Chitty, 2004, 37-067; Wallace and Hudson, 1995, no 86-4.150). In the German law, the articles no. 643 and 642 (art-642, para-2, 643) and various other commands in the civil codes of other countries such as (Australia, article 1168), (Netherland, article 248-6), (Belgium, article 1134), (Spain, article 1258), (Italy, article 1996) (Barendrecht et al., 2007), also the general national rules and conditions of some of the mentioned countries (Austria-ONORM, B, 20110-9.1) and (The Netherlands-UAV, 1989-Ort-5.1), as well as numerous other cases confirm the employer commitment to deliver the site and the right of access. The effort of the employer to give the right of access does not have consequences, but it should be achieved. The mentioned commitment is a commitment to result. The employer should prove that he/she had given the right of access and the workshop to the contractor.

\subsection{Contract Price and Payment}

According to the suffix 14-1 (EPC-Red Book-14.1) on the general conditions of FIDIC and article 37 of the general conditions of agreements by the Management Organization, the employer should pay according to the task done based on the contract, after the legal and contractual deductions. The first installment of the earnest money is payable during 42 days after issuing the acceptance, or 21 days after receiving the document guarantee (Red Book 14.7) and temporary statement (Red Book-14.7). The definite statement is payable during 56 days after receiving the certificate of final payment issued by the consulting engineering (Red book-14.8). Half of the deposit for goodness of doing the task is returned by issuing the certificate of delivering the task, and the second half would be returned by expiring the guarantee deadline and fixing the defects (Red Book-14.10). Through delivering and presenting the definite statement, the contractor would present the written affidavit that the total sum of the definite statement, which shows the completed account settlement is belonged to him/her according to the agreement (Red Book-14.12). According to the articles no. 36 and 37 of the general conditions of agreements by the Management Organization, the mentioned promises are changed to 20 days for earnest payment and 10 days for the temporary bill and 6 months for the definite statement.

According the article 2-107 of the Principles European Law on Service Contracts, the contract price should be paid when the constructor transfers control of the building or a part of it to the employer according to the article 2-106. According to the mentioned article, the transfer time is the payment deadline. The contract price should be paid after request of transferring and refusal of the employer.

In the European countries, some countries pay at the time of delivering and transferring control of the building (Belgium and Netherland, article 694 cc 7-758; Spain, article 694 cc 599; Greece, article 694 cc 694), some others pay at the time of acceptance (Germany, article 641; Germany, article 645 and 654; Poland, article 1599), and some others pay at the time of completing the building (e.g. England (Wallace and Hudson, 1995, Not, 4-140) and in Austria, article 1170) which have different consequences. In the turnkey and design-build contracts (EPC, Red Book) in which the contractual price is usually fixed (Red Book EPC- 14.1), a part of the price is paid as the earnest payment (Red Book EPC-14.2), and a part of it is paid as the temporary payments (EPC-14.3) till the project is finished, and the final bill is paid by presenting the certificate of work implementation by affirmative documents and approval by the consulting engineer and confirmation by the employer (EPC-14.11). In this case, the commitment of employer is commitment to result, because his/her endeavor in paying the contractual price would not deny his/her commitment.

\subsection{Commitment to Inspection, Supervision and Acceptance}

In the general condition of FIDIC agreements, inspection and supervision on executing operation is different in the design and construction agreements (Red Book-3.1) and the agreement of turnkey (EPC-3.1). In the turnkey agreements, the employer just introduces a representative, and the responsibility for complete supervision on executing operation is assigned to the contractor. In the general conditions of design-build agreements of FIDIC (Red Book-3.1), the employer would assign a supervisor engineer on the work to perform the duties leaved over 
him/her. Any approval, certification, test, inspection, ordering, requesting, or suggestion is done through him/her. However, performing the mentioned duties would not exempt the contractor from any responsibility, and he/she is responsible based on the contract. The supervisor engineer has the right to order to the contractor (Red Book-3.3), he/she should accept his/her orders, and orders are in the written form.

According to the article 1-105 in the Principles of European Law on Service Contracts, the employer is not bound to inspect and supervise the construction. However, with regard to his/her duty in cooperation, he/she can inspect and supervise the executing process. If it is appointed that the constructor uses certain materials and elements, he/she does not have the right of performance without permission of the employer. The lack or low efficiency of inspection and supervision, and even the acceptance do not exempt the constructor from his/her responsibilities completely or partially. This rule is observed even when the employer is obliged to inspect, supervise, and accept the building.

According to the article 2-105 in the Principles of European Law on Service Contracts, common inspection and supervision is a permissible affair, and there is no duty on the mentioned principles. If any defect is found during the inspection and supervision, and no warning is done according to article 1-113 on the mentioned principles, compensating damages is under the influence of time passing written in the article 2-111 on the mentioned principle.

In all European countries, inspection and supervision is in the rights of the employer, because his/her inspection should not interfere with the execution process of the project (Jansen, 1998, 354). However, in most European countries, supervision on huge construction projects is a common and necessary affair, according to the general conditions of ordinary agreements. In some countries such as France and Spain, in small projects, an architect supervises the construction. In Germany (VOB/B-art, 4), Portugal (CC, Art, 1209) and Austria (ONORM, A, $2.11,2069)$ the same trend is dominant. However, in the general conditions of agreements by the Management Organization, direct supervision of the employer (article 32 and 33) does not reduce the responsibilities of the contractor, and in the National Rules for Construction, supervision is an obligatory task, and the supervisor should confirm it (the second subject in the National Rules for Construction).

\section{Nature of Contractor Commitment and Its Evidences}

In construction contracts, most commitments are focused on the contractor or constructor. $\mathrm{He} / \mathrm{she}$ should try his/her best to achieve the final result. In the following paragraphs, some of the important commitments of the contractor in the Principles of European Law on Service Contracts (PELSC), the general conditions of FIDIC agreements (Red Book, EPC) and some of their evidences are investigated.

\subsection{Commitment to Safety and Care}

As a rule, (Red book, 4.22), the contractor is responsible for protecting people, works, and materials from beginning to the end of the project (articles no. 20 and 21 in the general conditions of agreements by the Management Organization, EPC-10.1). If any damage occurs during the construction (EPC-17.3), the contractor is responsible for compensating losses and repairing them, and also he/she is responsible for damages resulted from the acts of his/her employees (article 14 in the periodic responsibility law). "Commitment to safety is a contractual, custom or legal commitment of a party to the other party to be careful about his/her life and properties or a third person during the operation executing process or common or given use of traded goods" (Khedmatgozar, 2010). Commitment to observation and safety basically includes contracts in which the committed party undertakes it professionally (William, 1971, 664). In construction, even if there is no explicit commitment, the contractor is committed to safety practices and is responsible for compensation. Observing accuracy and conventional cares do not save the contract from his/her responsibilities. Safety commitment in this sense, in terms of subject matter, is commitment to result (Ibid, 24). Safety commitment to result may be based on law or contract. Based on the Principles of European Law on Service Contracts, article 103-2, the constructor should observe the conventional precautions to prevent damages to the building. Duty of care has a different name in various European countries, e.g. it is called "Skills Pledge" in Britain, "Duty performance by expert" in Sweden (AB, Art 92), and "Duty of care" in Greece (PECL, 18,108). In Britain, commitment to implement work is based on reasonable skills (D-Wallace, 1995 no-37-069). In most jurisdictions, responsibility for building efforts, standards and responsibility for compensation of work and other goods and people have been defined (Jansen, 1995, 252-CPA Art,9.13). In the German law (BGB Art.635), Austria (ONORM-B-2110-5.13-5.14.2) and Poland (CC-Art, 652), constructors is responsible for the care and safety of the status quo and prevention of damage. In construction contracts, according to the FIDIC standard, including the standard technical principles, safety commitment to the contract subject and protection of property is close to commitment to result, but commitment to employees is close to commitment to means. 


\subsection{Commitment to Compliance with the Purpose}

According to the Principles of European Law on Service Contracts, article 104-2, the constructor should deliver a building in accordance with the contract in terms of quality and quantity of materials, unless the contrary is agreed. The building must be constructed for a particular purpose or conventional purposes if the parties do not specify any purpose. If orders are issued by the employer, he/she does not have a right to invoke damages in the case of a mismatch. This article contains a principle based on which the constructor is committed to compliance the building with the purpose, unless it is proved that the incompliance was out of his/her control. If the constructor is not able to deliver the building in accordance with the specified purpose, he/she is forced to notify the employer. If a section or a combination is not compliant with the conventional and natural purpose, although the entire building is appropriate, it is not considered to be compliant with the purpose (Barendrecht et al., 2007, 342). Compliance with purpose should be specified to the contractor when the contract is concluded (PELSC, 1.111). Article 104-1 in the Principles of European Law on Service Contracts focuses on the natural purpose of the requested building. However, in the construction industry, there are many cases in which particular purposes are determined in preliminary discussions (e.g. pond construction for testing a particular type of boat). In most European countries, commitment to compliance with purpose generally accepts absolute responsibility of the characteristics specified in the contract (Wallace and Hudson, 1995, no-H.080, CC, Art 1667. Italy-CC, Art 1167-CC Art 1208-Portgual-CC, Art 689-688-Greec).

In all these countries, the constructor is committed to observe compliance with purpose, including specified or conventional purposes. Thus, in these countries, the constructor is committed to result and is forced to deliver a building compliant with the purpose, unless it is out of his/her control because of obstacles. Today, courts in Britain consider the principle of compliance with a purpose for buildings and other structures, although the traditional rule is different in the UK, and the constructor should prove that he/she implemented the building according to maps and details in a skillful manner with proper materials. In this case he/she is not responsible if the employer trusts the constructor skills. There is an implicit guarantee that the contract would normally be compliant with its purpose.

The case is different in traditional construction contracts and turnkey and design-build contracts. In turnkey contracts, the constructor is able to control a wide range and the subject is governed by the contractor. But in traditional and design-build contracts votes of the employer architect are gradually involved in implementation and reduction of the manufacturer's ability and independence. Therefore, compliance with purpose is different in these contracts (PECL, 8.108). In general terms of FIDIC, the contractor is committed to result, design, completion of work in accordance with the contract (Red Book-EPC, 4.1) and he/she must compensate all defects arising from the work. Moreover, the work must be compliant with the specified or conventional purpose and be correctly implemented with the necessary stability (EPC-4.1). In this case, the constructor is committed to result and efforts are worthless.

\subsection{Commitment to Delivery}

The constructor is committed to implement and deliver the building. Based on the Principles of European Law on Service Contracts, article 106-2, if the constructor states that the entire building or an independent part of it is useable, then he/she can ask for delivery and the employer should accept it in a reasonable deadline after declaration. The employer can reject to deliver it, if the building or a part of it is not in accordance with the contract so that this lack of consistency makes it unsuitable for use.

If the employer accepted, the constructor is not free from responsibility. This principle can be seen when the employer is committed to inspection and supervision under a contractual obligation. According to the mentioned article, the constructor announces that the work is ready to be delivered, unless it has serious defects. Minor defects or defects that may be repaired in a short time do not delay the delivery (CC, Germany, 640-Barendrecht, 2007-372), unless they make the building unusable. From this article, it is concluded that building delivery does not mean that the rights related to implementation are ignored (Barendrecht et al., 2007).

In all jurisdictions, the constructor should announce that the work is ready for delivery and the delivery is done in a conventional time and if the acceptance is not explicit, it is usually tacit (CC-Art, 7-758 Nether Lands) -(CC, French, Art, 1048) -(LOE-Spain, Art 6). After delivering and transferring liability, the contract price must be paid. According to some votes in Poland, obligation to accept work is independent from adoption of quality (Judgement of the supreme court of 5-3-1997, 11 CKN-28-97-OSNC-NR-6-7-Poz 90). In English law, the general rules of contracts for delivery are met (Wallace and Hudson, 1995, not, 37). According to the FIDIC rules (Red Book-10.1), if tests are conducted successfully, the work will be delivered by the employer. If works are completed according to the contract and the delivery certificate is issued, or it is assumed that the delivery 
certificate will be issued, if the supervisor engineer fails to issue the delivery certificate or no action is done within 28 days after the contractor request, it is assumed that the delivery certificate is issued at the end of the deadline (EPC-10.1). This concept can be seen in general terms of contracts issued by the Management Organization (article 42) for definite delivery.

\subsection{Responsibility for Defects}

According to the general terms of FIDIC rules, (Red Book-EPC-11.1), the constructor is committed to compensating and troubleshooting before the expiry of the guarantee deadline. The constructor is responsible for the entire work (Red Book-11.2), so that the work is assigned to the map that constructor is responsible for it. Troubleshooting does not last more than two years (Red Book-11.3). If the constructor refuses to fix defects or compensation, and the deadline determined by the employer is expired, according to the FIDIC, article 11.4 (Red Book-11.4), the employer can directly fix the defects with the contractor money in a conventional manner, but the contractor is not responsible for the implemented work. The employer works on behalf of the contractor according to the mentioned conditions.

Implementation of commitments does not mean that all obligations are undertaken, unless the engineer issue the implementation certificate for the contractor. The contractor should immune the employer from losses (EPC-17.1), including employer staff, lawsuits, damages losses and costs, including physical damages or otherwise related to design, implementation, finishing and defects unless they can be attributed to negligence or breach of contract by the employer.

In the legal systems of Britain and Germany, lack of supervision does not affect responsibility of the contractor, but in many countries, if at the final inspection or shortly after it, the constructor defects are not announced, the issue is excluded (cc art. 1219 Greece - cc art 692 Netherlands- cc art 758 Sweden). Legal precedent in France maintains the responsibility and it is assumed that the defect was hidden at the time of delivery (Cass-Civ-111-23-November-1976). In the English law, where supervision is mutually agreed, poor performance is not considered as a defense for the constructor (Kingston, V. Hading-1892-2QB-H94-Cout of Appeal). However, in the Netherlands (UAV-1989), some provisions make the constructor free from responsibility in the case that the employer or his/her representative was able to notice fixing defects but did not that (Jansen, 1998, 374). In Portugal, according to the article $1218 \mathrm{cc}$, the employer is obligated to inspect the work before delivering. Failure to inspection means that the work is completely accepted. But, there are two different times in the Spanish law: 1- Time of delivery; 2- Time of acceptance. At the time of delivery, subject of the contract is physically delivered to the employer, but time of acceptance is the time when quality and features of the work are accepted. Delivery may be done before, after or at the same time with acceptance (LOE-Art-6). The employer can refuse to accept the work, but the reasons should be reported, unless the contrary is agreed. Within 30 days after delivery, the building should be finished. The 30 days' deadline starts since certification is issued by the employer.

If the employer does not report any defect after 30 days, it is a tacit acceptance. Although, in many European countries there is no obligation to inspect, but lack of inspection has some consequences (art 758-7 cc and $640 \mathrm{cc}$ Netherlands-Germany). Because, according to the mentioned rules, the constructor is not responsible for defects that could be discovered and announced by the employer reasonably at the time of delivery. In Poland, inspection (Art $563 \mathrm{cc}$ ) is related to the nature of the contractual relationship. If the contract is concluded between persons employed in economic activities, inspection is mandatory.

In Sweden, there is a difference between hidden and apparent defects (AB92). Defects existing at the time of final inspection that were not warned are hidden defects and the other imperfections are apparent. The constructor is only responsible for not warned defects. But this rule does not apply to hidden defects.

\subsection{Implementation of the Exact Terms of Commitment and Repair}

According to the principles of European Law on Service Contracts, article 104-2, if the constructor does not deliver the building, the employer has not the right to ask for repair of non-compliance and implementation of the exact terms of commitment based on the article 109-2. Unless firstly, the repair is not illegal and impossible, secondly, repair does not require costs, and thirdly, implementation does not include service, work or a personal attribute based on personal relationships. If the constructor fails to deliver the building (PELSC-2-1.4), the employer can repair the non-compliance only if he/she can do that, and the employer can ask for repair of damages (PECL, 9-201) for any not compensated losses from the constructor. There is no hierarchy for compensation in the European principles (James, 2002, 387). The committed person is free in implementation to choose among the available ways of compensation. In construction, the initial compensation is an implementation of the exact terms of commitment that usually has a form of repair and parties are interested to 
accept it. Repair and implementation of the exact terms of commitment is not broad. Where, implementation of the exact terms of commitment leads to unusual delay and unreasonable difficulty for the employer, the constructor cannot insist on repair of non-compliance. The Civil Code of Netherlands, (article 759-7, CC) gives the right of implementation of the exact terms of commitment to the employer unless repair costs are not appropriate. In Poland, according to the article $636 \mathrm{CC}$, the employer has the right to ask for the specified time of fixing the defects, and if the defects are fundamental, he/she has also the right to request depreciation. According to the article $1221 \mathrm{CC}$, Codes of Portugal and Austria (Art. $932 \mathrm{CC}$ ), the employer has the right to ask the constructor for fixing defects. In Sweden, constructor is responsible for apparent defects during a two-year guarantee. In the UK, court issues order of implementation of the exact terms of commitment to a construction contract, if the construction work is adequately defined in the contract (Wallace and Hudson, 1995, 4-301).

In France, according to the article $1792 \mathrm{BC}$, the right of repair is developed for one year after the delivery. In Germany, according to the article $634 \mathrm{CC}$, there are defects that make the building unusable and should be fixed. But there are some defects that do not limit the use of the building, but reduce its economic value. The action is in accordance with the above mentioned articles. Of course, there are other ways of compensation, including termination of contract and cost reduction, but implementation of the exact terms of commitment is one of the best solutions. Therefore, it seems that in this case, the constructor commitment is commitment to result and he/she should implement the exact terms of commitment or pay for losses resulting from the breach. In the general terms of FIDIC contracts (EPC-Red Book-11-1), a contractor is obliged to implement the exact terms of commitment and resolve defects and imperfections on the specified deadlines. The contractor must fix defects with his own money and risk. However, constructor is responsible for non-compliance of equipment, materials, quality of implementation of the contract and operation and maintenance attributed to him/her.

\section{Conclusions}

1) Commitment is a consequence of a contract. It is difficult to prove fulfilling the commitment and observing contractual purpose. Lawyers are trying to identify ways to prove faults. To this aim, some of the French Lawyers classified commitment as commitment to result and commitment to means, i.e. if one is committed to achieve the result, it is a commitment to result, and if he/she tries to achieve that, it is a commitment to means.

2) Commitment to result follows a fixed limit, i.e. achieving the result, but in commitment to means, the behavior of a normal person is the standard. Some criteria have been proposed to distinguish these two types of commitment, including the intention of the parties, the possibility of implementing the contract subject, and probabilistic nature of the result.

3) In construction contracts, constructing, repair and modification of buildings are usually the subject and the main obligation. According to the normal processes, general conditions of FIDIC contracts, Principles of European Law on Service Contracts, and domestic regulations, including general conditions of contract issued by the Iranian Organization of Management and National Building Regulations, the parties want to achieve the desired result, unless when implementation of the commitment is not possible.

4) Most of the employer commitments in implementation of the contract subject in general conditions of FIDIC, Principles of European Law on Service Contracts, and general conditions of Management and Planning Organization include delivery of land and site, relevant information, paying for temporary and definite bills, and compliance with the implementation. Delinquency is the basis of responsibility for timely implementation of the commitments and if the obligations are not fulfilled, the responsible party should compensate the other party's losses. Non-delivery of land or non-payment of the contract price in accordance with the detailed implementation program can cause irreparable losses to the constructor. In European countries, the payment time is different. In some countries, time of delivery and transferring control of the building, in some others the time of accepting and verifying, and in some of them the time of completing the building is defined as the payment time. The effects of each of these times are different, but in the Principles of European Low on Service Contracts, article 107, time of delivering and transferring control of the building is the criterion. But in the general conditions of other contracts, costs are gradually paid in the form of advance payment, temporary and definite bills.

5) In the general terms of FIDIC contracts, European principles, and regulations of most countries, supervision is one of the employer rights, though supervising has strength and weakness in general terms of different contracts. Supervision or lack of supervision does not reduce the responsibility of the constructor.

6) The main contractor commitments in implementation of the contract subject include: Commitment to care and safety, commitment to compliance with purpose, delivery of the building, defects and implementing the exact terms of commitment. The constructor is committed to implement the contract subject in accordance with the 
intended or conventional purpose. After implementation, the contract subject should be delivered to the employer on the deadline. Delivery does not cause that the constructor be free from liability arising from defects and supervision of the employer in all the general conditions of contracts and regulations do not lead to prohibit or reduce liability. If the constructor does not implement the building, according to the terms of the contract, the employer can ask for implementation of the exact terms of commitment and repair, if the repair is not illegal or impossible, and does not require unusual costs. However, the main obligations of both parties in construction contracts are commitment to result. However, in the implementation of the main obligation, there are some secondary obligations and numerous provisions that outline the contract execution process. If each of the parties fail to participate in implementation, the party should compensate losses.

\section{References}

Alhosseini Almaraqi, M. F. (2004). Alanavin. Society of Teachers of Qom Publications.

Alsanhouri, A. R. (1970). Alvasit: the new Civil Code. Cairo Publications.

Barendrecht, M. et al. (2007). Principles of European Law on Service Contracts (Study Group on European Civil Code) (PELSC). Bruylant-Publishers Ltd. Berne.

Chitty. (2004). Chitty on Contracts-SWEET \& MAXWELL (29th ed). London.

Consumer Protection ACT, 2008.

Ghasemzadeh, M. (2009). Principles of contracts and commitments. Dadgostar Publications, Tehran.

Jafari Langroudi, M. J. (1984). Civil rights: Rights of obligations. Tehran University Press.

Jafari Langroudi, M. J. (2003). Legal terminology. Ganj-E Danesh Library Publications, Tehran.

James, M. F. (2002). Construction law (2nd, ed.). Palgrave, New York.

Jansen, C. E. C. (1998). Towards a European building contract law: Defect lability. W.E.J-Tjeenk Deventer.

Katozian, N. (1985). General rules of contracts (Vol. 1). Behnashr Publications, Tehran.

Katozian, N. (1987). General rules of contracts (Vol. 2). Behnashr Publications, Tehran.

Katozian, N. (1989). General rules of contracts (Vol. 3). Behnashr Publications, Tehran.

Katozian, N. (1997). General rules of contracts (Vol. 4). Publishing Co., Tehran.

Katozian, N. (1999). General rules of contracts (Vol. 5). Publishing Co., Tehran.

Katozian, N. (2000). Civil rights, the theory of general obligations. Dadgostar Publications, Tehran.

Katozian, N. (2002). Philosophy of law. Publishing Co., Tehran.

Katozian, N. (2005). Compulsory liability. Tehran University Press.

Khedmatgozar, M. (2010). Safety commitment in contracts. Jungle Publications, Javdaneh.

Khodabakhshi, A. (2013). Claims rights. Publishing Co. Tehran.

LOE-General Guide to contract types for Requirements Officials, 2008-In S Pain.

Mortazavi, A. H. (2013). Rights of obligations, commitment to means and result. Jungle Javdaneh Publications, Tehran.

Najafi, M. H. (1974). Javaherol kalam fi sharhe sharayeol Islam (Vols. 23-43). Darolehya Altaras Alarabi Publications, Beirut.

ONORM (Osterreichisches-Normung Sinstitut) Austrian-Standards, 2014.

Principles of European Law on Service Contracts (PELSC), (2007). Utrech University.

Shahidi, M. (2004). Principles of contracts and obligations. Majd Scientific and Cultural Journal, Tehran.

UAV-Uniform administrative conditions for the executive of works. (1989). Stitching Institute of Voor Bouwrecht

VOB-Constraction Contract Procedures in German, 2012.

Wallace, D., \& Hudson, S. (1995). Building and engineering contracts (11th ed., Vol. 2). Sweet \& Maxwell London.

William, L. (1971). The law of torts (4th ed). West publishing co. -USA.

Yellow Book, (FIDIC) 2014. 


\section{Copyrights}

Copyright for this article is retained by the author(s), with first publication rights granted to the journal.

This is an open-access article distributed under the terms and conditions of the Creative Commons Attribution license (http://creativecommons.org/licenses/by/4.0/). 